\title{
Rural Taxation Reforms and Compulsory Education Finance in China
}

\author{
Wen Wang \\ Department of Public and Social Administration \\ City University of Hong Kong \\ Tat Chee Avenue \\ Kowloon, Hong Kong \\ 852-3442-8273 \\ wenwang@cityu.edu.hk \\ Zhirong Jerry Zhao \\ Hubert H. Humphrey Institute of Public Affairs \\ University of Minnesota \\ \#246 Humphrey Center \\ $301,19^{\text {th }}$ Avenue South \\ Minneapolis, MN 55455 \\ 612-625-7318 \\ zrzhao@umn.edu
}

(May 17, 2010)

Preparing for the symposium on

"Public Budgeting and Financial Management Development in China" for the Journal of Public Budgeting, Accounting \& Financial Management

Wang, W., \& Zhao, Z. J. (2010, May). Rural taxation reforms and compulsory education finance in China. In Public Budgeting and Financial Management Development in China'Symposium, Journal of Public Budgeting, Accounting \& Financial Management. http://dx.doi.org/10.2139/ssrn.1669908 


\title{
Rural Taxation Reforms and Compulsory Education Finance in China
}

\author{
Abstract \\ In recent decades, the responsibility for the financing of compulsory education \\ in rural China has rested with townships and villages which, with limited tax authority \\ and uneven revenue capacity, increasingly relied on a plethora of arbitrarily imposed fees \\ for funding. To reduce farmers' fiscal burdens, since 2000 the central government has \\ installed a series of rural taxation reforms. Correspondingly, the central government \\ shifted the administrative responsibilities of rural compulsory education to the county \\ level in 2001, and implemented a series of policies to make up for the loss of revenues to \\ education. Using a provincial-level dataset from 1998 to 2006, this study examines \\ whether and how the rural taxation reforms have affected the adequacy and equality of \\ compulsory education finance in China, and addresses related theoretical and policy \\ implications from the perspective of intergovernmental fiscal relations.
}




\section{Rural Taxation Reforms and Compulsory Education Finance in China}

\section{Introduction}

The provision of nine-year compulsory education in China since 1985 has been very decentralized, with major responsibility for its financing resting with lower levels of government such as townships and villages in rural areas, or cities and districts in urban areas. Since the 1990s, some local governments, with limited tax authority and uneven revenue capacity, have increasingly relied on extra-budgetary revenues collected from a plethora of arbitrarily imposed fees. The result was an untransparent and widely dispersed school finance system, in which poor and rural areas faced the dilemma of underfunded education and excessive local taxation burdens. These challenges were manifestations of China's imbalanced intergovernmental fiscal arrangements, which combined a highly centralized revenue system with very decentralized fiscal responsibilities for public service delivery, in particular after 1994's tax-assignment reform (Lin et al. 2007).

Since 2000, the central government in China has initiated a series of rural taxation reforms to address the issue of widespread rural discontent over excessive fiscal burden (Lin et al. 2007). In the first stage, "Tax-For-Fee," all rural fees (including those for compulsory education) were removed and replaced with an agriculture tax and related surcharges. Early evidence suggests that farmers' burdens may have been dramatically reduced as a result of Tax-For-Fee. However, there are concerns about how the reform has affected the adequacy and equity of China's rural education finance (Kennedy 2007).The second stage of rural taxation reforms was launched in 2004, with the goal of 
phasing out the agricultural tax entirely within three years (Li 2008). The central government has accordingly made several adjustments to the provision of rural education finance. But the full impact of this recent reform on China's compulsory education remains unclear. How did the rural taxation reforms change the previous finance system for compulsory education in rural China? What has been their impact on the adequacy and equality of funding for compulsory education in rural areas? What kind of problems still exists in the current compulsory education finance system for rural China? Using a provincial-level dataset from 1998 to 2006, this article aims to answer these questions in the context of intergovernmental fiscal relations.

This paper is organized into six sections. Following this section is a description of China's education finance system reforms since the 1980s. The third section traces changes of China's rural education finance policies resulting from recent tax reforms. Section four summarizes previous studies on the adequacy and equality of China's compulsory education. Section five discusses data and research questions, and presents empirical results. The final section concludes and addresses theoretical and policy implications.

\section{China's Compulsory Education System Since 1985}

In 1985, China established a system of nine-year compulsory basic education, which included primary and lower-secondary education (Tsang 1996, 2000). Launched correspondingly was an education finance reform, which had two defining characteristics: decentralization of the administrative structure, and diversification in the mobilization of educational resources. First, the decentralization of education 
administration was based on the principle of "local responsibility and administration by levels," that is, different levels of compulsory education were administered and financed by different levels of local government. ${ }^{1}$ In rural areas, townships and village governments were responsible for the provision and financing of lower-secondary and primary education, respectively. In urban areas, cities and urban districts were responsible for the provision and financing of lower-secondary and primary education, respectively (Tsang 2002).

Second, financial resources for basic education came from both budgetary funds and extra-budgetary funds. The budgetary funds included two sources: allocations of local governments' own-source revenue, and categorical grants from central and provincial governments, which constituted only a minor source of funding for education (Tsang 1996). The extra-budgetary funds included funding from local surcharges/levies ${ }^{2}$ and social contributions, such as individual or organizational donations (Tsang 1996). After the 1985 education finance reform, extra-budgetary funds generated at the local level constituted an increasing share of total resources to China's compulsory education, and thus local governments (at and below the county level) became the primary financing source for budgetary expenditures on compulsory education (Tsang 1996; Tsang 2001).

\footnotetext{
${ }^{1}$ Fiscal and administrative responsibilities in China are organized in a five-level hierarchy: (1) the central government, (2) provincial-level governments, (3) prefecture-level governments, (4) county-level governments, including counties (in rural areas) and county-level cities (in urban areas), and (5) townshiplevel governments, including towns (in rural areas) and districts (in urban areas). For a description of China's governmental structure, please see http://www.economicexpert.com/a/Political:divisions:of:China.htm (retrieved 03/30/2009).

${ }^{2}$ In rural areas, educational levies were imposed on agricultural taxes paid by rural households, and revenue from these levies was used for education in the same locality. As additional payments based on existing taxes, education levies were not regarded as "official" taxes. Therefore, levies were flexible; they did not need a lengthy process for approval and adoption, and were not regulated by law (Tsang 1996).
} 
The 1985 reform was successful in mobilizing additional resources for compulsory education. However, research shows that the level of government investment in education was still inadequate compared to other developing countries (Tsang 2000). In addition, the over-decentralization of financing compulsory education put a great financial strain on local governments, especially in rural townships and villages. With limited investment from higher levels of the government and uneven levels of economic development and fiscal capacity in different places, compulsory education encountered significant financial difficulties in many poor areas, and there were substantial and widening education fiscal disparities across locations. These deficiencies persisted and even intensified through the 1990s (Tsang 2000).

\section{Changes of Rural Education Finance Due to Recent Tax Reforms}

Since the establishment of the compulsory education system in 1985, China has had two major rounds of general tax reforms: the 1994 tax-assignment reform and the rural taxation reforms since 2000 .

\subsection{The 1994 Tax-Assignment Reform}

The 1994 tax-assignment reform established a new taxation system with dedicated central, local, and shared taxes, and created a new structure of tax administration (Wang 1997). As a rearrangement of intergovernmental fiscal relations between the central and provincial levels, the reform led to a higher concentration of fiscal capacity at the central level while keeping many fiscal responsibilities such as education or public health with lower level governments (Lin et al. 2007). The effect of the 1994 reform on China's compulsory education has not received much attention in the literature so far. First, the 
reform was limited to budgetary allocation, while China's compulsory education by that time had relied more on extra-budgetary funds including local surcharges/levies or social contributions. Second, the reform was limited to the fiscal relationship between the central and provincial governments (Zhao 2009), while budgetary allocation for compulsory education was determined mostly within provinces.

However, the 1994 tax-assignment reform had some significant, albeit indirectly, impact on China's education finance. First, with more financial resources controlled by the central government, provincial governments were left with a smaller share of budgetary funds to allocate. Second, some provincial governments followed suit to centralize fiscal resources within their provinces, leading to fiscal stress in sub-provincial governments. Lastly, with reduced fiscal capacity, provincial, and especially subprovincial, some provincial governments have reduced budgetary allocations for compulsory education (among other local public services) while implicitly allowing local governments to use informal (or even illegal) levies to make up the difference, e.g. "turning a blind eye to illicit fee collections" (Lin et al. 2007). Over time, these informal levies were abused in some rural areas and led to excessive tax burden for farmers, triggering rural taxation reforms in recent years.

\subsection{Rural Taxation Reforms Since 2000}

Before 2000, China's rural tax revenue came from four major sources. The first was the formal agriculture taxes levied at the national or provincial level. The second source was an implicit tax known in China as "price scissors," through which the central government extracted a profit from farmers by mandatory procurement of grains at below-market prices and then selling them to urban residents at higher prices. The third 
source was several standard surcharges ("santi wutong") collected by rural governmental units (Lin et al. 2007). ${ }^{3}$ As the fourth source, townships and villages also collected additional discretionary revenues. One early approach of such collection was to add a margin for household grain procurement on top of the central government's quota. This approach, however, ceased to work when the central government's "price scissors" diminished as a result of market liberation of China's agriculture sector in the late 1980s. In response, in the 1990s many rural areas (especially those in agriculture-based regions) experienced a surge of diverse, illegal local fees that were imposed on farmers, without explicit government regulations or legislation. ${ }^{4}$ These fees were not formally budgeted, and constituted a significant share of farmers' excessive tax burden, leading to widespread rural discontent. To address this issue, since 2000 the central government has installed a series of "Tax-For-Fee" rural taxation reforms, removing all fees and replacing them with agriculture taxes and related surcharges (Lu et al. 2004). To compensate for the loss of revenue, the reform raised the agricultural tax to $7 \%$ on average, ${ }^{5}$ and allowed a surcharge to agricultural taxes (nongyeshui fujia) equivalent to the maximum of $20 \%$ of the tax payment imposed on farmers (Yep 2004).

The Tax-For-Fee reform helped to lower farmers' burden and reduce rural tension in China (Yep 2004), but it has been controversial because of its undue effects on the

\footnotetext{
3 This included "five township-pooling funds" (wutong) to township governments, providing basic public goods such as education, public security, and state mandated family planning, etc., and "three village levies" (santi) to village collectives, providing for collective capital accumulation, collective welfare funds, and cadres' salaries.

${ }^{4}$ Examples include charges for road and school construction and other local improvement projects, purchase of insurance, charges for marriage certificates or housing construction, prohibitive prices for electricity and tap water, and so on (Lin et al. 2007).

${ }^{5}$ Before the reform, the national average agriculture tax rate was about $15.5 \%$ of a state-defined tax base of "expected output" that had been fixed for several decades. Because the expected output was calculated on the basis of obsolete data collected decades earlier, and the agricultural productivity was often deliberately under-estimated, the real agricultural tax rate was in the range of $2-3 \%$. Therefore, the adjustment of the tax rate to $7 \%$ in 2000 was, in fact, a raise (Yep 2004).
} 
fiscal capacity of local governments to provide public services such as compulsory education (Wong and Bird 2005). The reform abolished extra-budgetary fundraising for education but did not specify a certain percentage of the agricultural tax (or surcharge) for compulsory education. Thus, the inadequacy in funding for compulsory education has become a more significant problem (Kennedy 2007). ${ }^{6}$ The provincial governments increased their investment in education for townships and villages, but the transfer payments from above did not fully compensate for the loss of funding for village and township governments (Yep 2004). ${ }^{7}$ In an effort to correct this problem, in 2001 the Chinese central government shifted the administrative responsibilities of rural compulsory education from the village and township level to the county level, and urged local governments to make education a priority in their budgetary funds and intergovernmental transfers, ensuring adequate compulsory education spending in rural areas ( $\mathrm{Lu}$ et al. 2004). Anecdotal evidence, however, shows that this initiative did not alleviate the problem of inadequate funding for compulsory education and the fiscal gap between urban and rural schools (Kennedy 2007; Yep 2004; Li 2008). After the abolition of local fees, many schools could not afford to repair and renovate their dilapidated school buildings, to pay the full amount of their teachers' salaries in time, or to maintain school operations (The Development Report of China's Education 2006).

In 2004, the rural taxation reforms moved to a new stage as the government decided to phase out the agriculture tax, which was completely abolished in 2006. Also

\footnotetext{
${ }^{6}$ Anhui province, for example, had a total decrease of 1.84 billion RMB (about $\$ 0.24$ billion) in revenue for village and township finances after the first year of the reform, a 30-40\% drop on average for each village and township government.

${ }^{7}$ For example, the total expenditure for compulsory education as a percentage of total expenditures declined from 25.52 to $18.17 \%$ in Anhui Province from 1999 to 2003.
} 
in 2004, the Chinese government implemented a "one-charge system" (yifeizhi) nationwide. The policy allows schools to collect one single charge from students for miscellaneous fees and textbooks based on the standard set for localities by the provincial governments. The charge was established to supplement operational expenditures for schools in a transparent and controllable way. ${ }^{8}$ In addition, the central government increased transfers to compensate for local revenue shortfalls, and created policies or incentives to streamline its local bureaucracy by downsizing local governments and cutting personnel expenditures (Kennedy 2007). The full impact of this recent reform on China's compulsory education remains unclear.

\section{Critical Issues: Adequacy and Equity of China's Compulsory Education}

To evaluate a system of education finance, there are three commonly used criteria: adequacy, equity, and efficiency (Levin 1995). Adequacy refers to the mobilization of sufficient resources to support a desired level of education services. Equity relates to fairness in resource mobilization and allocation. Efficiency in education resource allocation refers to maximizing the performance of education with given resources (Tsang 2001). In this article, we focus on adequacy and equity of China's compulsory education in rural areas, in particular, how they have been affected by the recent rural taxation reforms.

\footnotetext{
${ }^{8} \mathrm{See} \mathrm{http://www.moe.edu.cn/edoas/website18/48/info21948.htm} \mathrm{(retrieved} \mathrm{03/19/2009).}$
} 


\subsection{Adequacy of China's Compulsory Education}

Adequacy of education finance may be measured in many different ways. At the national level, two traditionally used measures have been: (1) the share of education investment on total Gross Domestic Product or Gross National Product (educationGDP/GNP share), with $8 \%$ normally considered as adequate, and (2) the share of public education expenditures in total governmental budget (education-budget share), with 20\% as a common benchmark (Carnoy 1995). The two measures, however, have been criticized as only accounting for the input side of education finance. Since the 1970 s, the World Bank has adopted a new measurement system that emphasizes education outcomes, tracking the enrollment in primary or secondary schools for certain age groups, the rate of adult illiteracy, and whether there is equal education opportunity for females (Carnoy 1995). Some of these measures have been used to evaluate the adequacy of China's compulsory education. For example, Li (2008) found that the average educationGNP-share rose to $2.6 \%$ in the late 1990 s from $2.2 \%$ before 1978 , and the average education-budget-share rose to $12.9 \%$ from $6.5 \%$ during the same period. These findings indicate the success of 1985 reforms in mobilizing additional resources. However, the education-GNP/GDP-share and education-budget-share were still much lower than international benchmarks.

Another way to measure adequacy of education finance is to analyze per-pupil education funding, the composition of resources, and how they are utilized. Tsang (2005) found that, in 1999, for China as a whole, per-pupil total (recurrent and capital) spending was 701 RMB (about \$85) at the primary level, 93.9\% of which was recurrent 
expenditures (mostly personnel cost). ${ }^{9}$ At the lower-secondary level, per-pupil total spending was 1,165 RMB (about \$140), 92.0\% of which was recurrent spending.

Commonly seen in developing countries, this high percentage of personnel cost in lowerlevels of schooling indicates that schools have limited capacity to provide resources beyond a minimal level of basic operation (Tsang 2005). ${ }^{10}$ Sometimes even the personnel costs could not be guaranteed by budgetary funds. Thus, schools had to rely on extra-budgetary resources (such as legal or illegal education surcharges and levies as well as miscellaneous fees) to make up for the gap in recurrent funding. ${ }^{11}$ Some areas, especially minority or poor and rural ones, had limited capacity in raising extra-budgetary resources and thus suffered from persistent financial difficulty (Tsang 2005).

\subsection{Equity of China's Compulsory Education}

The problem of unevenly financed compulsory education in China has attracted a lot of studies since the 1990s. Studies consistently find substantial disparities in per-pupil spending across areas and regions in primary and secondary education, and they also suggest a widening gap in per-pupil spending over time, particularly at the primary level.

Some of these studies used province as a unit of analysis (Tsang 1994, Jiang and Zhang 1999, Du and Wang 2000, Li 2008). According to Tsang (1994), in 1989, the topspending province spent as much as 5.2 times that of the bottom-spending province, in terms of per-pupil total school spending in primary education; the corresponding ratio

\footnotetext{
${ }^{9}$ Recurrent spending was allocated between personnel and non-personnel subcategories. Nationwide, personnel spending constituted about three quarters of the recurrent spending at the primary level and about two-thirds at the lower-secondary level (Tsang 2005).

10 Among recurrent expenditures, the non-personnel portion is broken down into several sub-categories. For both schooling levels, the largest spending item was minor repair and renovation; administrative spending was in second place. Teaching related items (instructional spending plus spending on equipment) combined for slightly more than one-quarter of non-personnel spending (Tsang 2005).

${ }^{11}$ In 1999, at the primary level nationwide, $37.2 \%$ of the total expenditure relied on extra-budgetary funds; at the lower-secondary level, the percentage was $42.4 \%$ (Tsang 2005 ).
} 
was 4.5 in secondary (both lower- and upper-) education. In 1997, these ratios rose to 9.2 in primary education and 7.1 in lower-secondary education; in 2000, they became 10.6 in primary education and 6.6 in lower-secondary education (Tsang 2001). Jiang and Zhang (1999) grouped the thirty provinces into three "Education Regions" according to the Ministry of Education's categorization of educational progress and capacity, ${ }^{12}$ and found that the ratio of total school spending among the three regions grew from 2.8:1.5:1.0 in 1988 to $3.0: 2.0: 1.0$ in 1992 .

Other studies of education finance disparities focused on the county level. Based on county-level data in 1997 and 1999, Tsang (2005) found that the spending gap was particularly substantial between urban and rural areas, and between coastal and other regions, while the gap between minority and non-minority areas was relatively modest. Several county-level studies used measures such as the Theil Index to measure and compare funding inequality of China's compulsory education within provinces or across provinces (Pan 2000; Wang 2002; Tsang and Ding 2003; Tsang 2005). The results showed that intra-provincial inequality is more pronounced than the inter-provincial, albeit the relative shares of the two inequalities vary in different studies. Most studies agreed that the intra-provincial variation accounted for around $70 \%$ of the entire regional disparities (Wang 2001; Pan 2000; Tsang 2005); some even found within-province inequality could account for more than $90 \%$ of total inequality, despite the fact that provincial governments are officially required to provide a balanced compulsory education among counties within a province.

\footnotetext{
${ }^{12}$ In 1994, the Ministry of Education categorized all provinces into three regions based on the progress and capacity in achieving the universalization of nine-year compulsory education and the eradication of adult illiteracy (Tsang 2005).
} 
Substantial and even widening gaps in China's education finance are also reflections of growing disparities in economic development and in the distribution of income across regions and areas in the country (Wang and Hu 1999). Many scholars found local wealth (GNP, GDP, or personal income) to be a significant predictor of the inequalities of compulsory education, indicating that China's compulsory education was not wealth-neutral (Tsang 1994; Pan 2000; Wang 2002; Ding 2003). In particular, regions with higher per capita output tended to spend more from both budgetary and extra-budgetary sources, and the difference on the extra-budgetary side was especially significant (Tsang 1994). Over time, education in turn becomes a significant determinant of income and the distribution of income (Chen 2003), forming a self-reinforcing vicious cycle of disparities. This is why most scholars who touched on this issue called for intergovernmental transfer for compulsory education to address the urgent issue.

\section{Data, Research Questions and Empirical Results}

We compiled provincial-level data about education finance and education development during 1998-2006. ${ }^{13}$ The education finance data include variables of education revenue sources and expenditure types for primary and lower-secondary schools in both urban and rural areas. In order to control for differences in the cost of public services delivery across provinces and over time, we adjust the financial data during 1998-2006 with the spatial price deflators provided by Brandt and Holz (2006). ${ }^{14}$

\footnotetext{
${ }^{13}$ Ideally we would like to use county-level data to examine the change on compulsory education not only across provinces, but also across counties within a province. But such data have not yet been available for the time period in which we are interested.

${ }^{14}$ The provincial spatial price deflators during the period 1984-2004 can be downloaded from http://ihome.ust.hk/ socholz/SpatialDeflators.html. The deflators in 2005 and 2006 were calculated according to Brandt and Holz's method with updated social and economic data (See Zhao 2009).
} 
Data about education development include rates of enrollment, percentage of school buildings in dilapidated condition, etc.

This study looks at adequacy and equity of compulsory education finance. In terms of adequacy, we compare the education-GDP share and education-budget share, the rates of enrollment for primary and lower-secondary schools by educational region, and by urban or rural areas. In addition, we analyze per-pupil education funding by the composition of resources and how they are utilized. In terms of equity, first we compare per-pupil education funding by revenue sources and expenditure categories. Then we use Gini coefficient to measure the inter-provincial disparities of per-pupil funding for primary and lower-secondary schools, for urban or rural areas, and for different revenue sources and expenditure categories. Finally, we use the decomposition of Gini coefficient (Lerman and Yitzhaki 1985) to analyze how different expenditure categories contribute to the overall dispersion of per-pupil total education spending.

\subsection{Adequacy of China's Compulsory Education after Rural Taxation Reforms}

In 2006, total school enrollment at the primary and lower-secondary levels reached 103 million and 56 million, respectively. The enrollment of rural primary and lower-secondary schools was around 2-3 times that of urban schools in 2006. The high enrollment in rural areas undoubtedly created great demand on the government for the provision of educational services. The annual enrollment of primary schools has steadily declined from 1998 to 2006; that of lower secondary schools has also begun to decline since $2004 .^{15}$ The general decline may have happened due to the implementation of onechild-per-family policy in the 1980s. We find that, in recent years, the reduction in

\footnotetext{
${ }^{15}$ The numbers of students for primary and secondary schools are based on authors' calculation of data from China Education Finance Statistical Yearbook for various years.
} 
enrollment has been especially significant in rural primary schools. This may have occurred in part because some rural and poor counties, after taking over the responsibility for educational finance after 2001, have consolidated and reduced the numbers of elementary schools to save costs, and thus more students may have dropped out of school because of the increasing inconvenience. ${ }^{16}$

We compared the education-GDP share and the education-budget share during 1991-2006. The education-GDP share has increased from $2.86 \%$ in 1991 to $3.26 \%$ in 2006, with the rate of growth becoming much faster after 2000. This indicates a higher level of adequacy for educational input since the rural taxation reforms, most probably thanks to a higher amount of intergovernmental education transfers. Nevertheless, the education-GDP share still has not reached the target of $4 \%$ set by the Chinese central government in 1993 (Tsang 2000). ${ }^{17}$ The education-budget share has fluctuated modestly around $13-15 \%$, still below the common international benchmark of $20 \%$.

Even though the total education expenditures in China have been inadequate at both primary and lower-secondary schools, some outcome measures show that China has made progress in its provision of compulsory education. For example, the percentage of school teachers with at least twelve or fourteen years of education in primary or lowersecondary schools has increased from 62.8\% and 27.1\%, respectively, in 1986 (Li, 2008) to over $95 \%$ in 2005 . The percentage of primary and lower-secondary school graduates

\footnotetext{
${ }^{16}$ Such cases have been identified through field investigations by Li (2008, p. 113).

${ }^{17}$ Data for education-budget share and education-GDP share are obtained from China Educational Statistics Yearbook in 2005.
} 
getting into the next level of schools has also increased from $69.5 \%$ and $40.6 \%$ in 1986 (Li, 2008) to $98.4 \%$ and $69.7 \%$, respectively, in $2005 .{ }^{18}$

Table 1 presents the breakdowns of per-pupil total spending for compulsory education. It shows per-pupil educational spending from budgetary sources in 1998 and 2006. In 1998, schools in rural areas heavily relied on extra-budgetary sources. For instance, at rural primary and lower-secondary schools in 1998, only around $60 \%$ of the total expenditures were funded by budgetary spending. In 2006, the share of spending from budgetary sources increased substantially and reached over $80 \%$ for both school levels in rural areas. Obviously budgetary sources had become much more important for education funding after the efforts of rural taxation reforms to reduce the burden of levies and surcharges in rural areas. To compare regional differences, in both 1998 and 2006 we see higher budgetary reliance for provinces in Region Three. This indicates that nongovernment education resources continue to be more abundant in Regions One and Two (Tsang and Ding, 2005).

For primary schools nationwide, the per-pupil personnel spending has increased from 399 RMB (about \$50) in 1998 to 1,560 RMB (about \$200) in 2006; for lowersecondary schools, the corresponding increase was from 620 RMB (about \$78) to 1,760 RMB (about \$220). For both levels of schooling, personnel expenditure as a share of recurrent spending (the percentage is not directly shown in the table) has increased significantly from 1998 to 2006 , suggesting that government budgetary revenue may have guaranteed more adequate personnel funding due to the reforms in recent years. This personnel-recurrent share is especially high in rural schools or for provinces in

${ }^{18}$ The 2005 statistics are based on authors' calculation of data from China Educational Statistics Yearbook in 2005 . 
Region Three, because this area has less capacity in raising extra-budgetary resources for recurrent spending. Compared to the exponential growth of personnel spending, the increase of capital spending, which relied heavily on extra-budgetary sources, has been marginal between 1998 and 2006 for both levels of schools in all regions. In rural areas, the price-adjusted per-pupil capital spending remained unchanged for primary schools, and even decreased for lower-secondary schools. This illustrates that insufficient capital spending remained a serious challenge for schools in rural areas.

In Table 1 we can also compare budgetary spending and personnel spending. Note that for primary schools nationwide, in 1998 the per-pupil budgetary spending was 378 RMB (about \$49) while the per-pupil personnel spending was 399 RMB (about \$51), which means that budgetary funds were not sufficient to guarantee the personnel cost alone. This gap was even bigger in rural areas, with $311 \mathrm{RMB}$ (about \$40) budgetary spending compared with $338 \mathrm{RMB}$ (about \$43) personnel spending, indicating that rural schools had to rely heavily on extra-budgetary levies (Tsang 2005). The situation was significantly improved in 2006, when the budgetary spending was 1671 RMB (about \$214) compared with $1560 \mathrm{RMB}$ (about \$200) for personnel spending. For lowersecondary schools, the pattern of improvement is similar although less drastic.

Table 2 presents further information about the change of revenue composition between 1998 and 2006. For primary schools, government budgetary funds increased from 52.2 billion RMB (about $\$ 6.7$ billion) in 1998 to 186 billion RMB (about $\$ 23.9$ billion) in 2006, while the share of budgetary funds to total education spending increased from $60.8 \%$ in 1998 to $84.3 \%$ in 2006 . Similarly, the share for lower-secondary schools increased from $57.6 \%$ in 1998 to $76.9 \%$ in 2006 . In comparison, the importance of extra- 
budgetary funds declined substantially over the period of 1998-2006. The share of total surcharges at both school levels dropped from around $15 \%$ in 1998 to $5 \%$ and $6.4 \%$, respectively, in 2006. Note that when we further examine the change of total surcharges (not shown in Table 2), we find that the amount of rural surcharges has declined drastically since the start of the agricultural tax reforms in 2000 , whereas other surcharges, especially urban surcharges, have increased constantly over the period of 1998-2006. ${ }^{19}$ Though the amount of total surcharges began to decline after 2000, it actually started to rise again after 2003 due to the rapid increase in the amount of urban surcharges. This echoes some survey findings by Lin et al. (2007).

\subsection{Equity of China's Compulsory Education after Rural Taxation Reforms}

Table 3 reports the Gini coefficients of per-pupil budgetary recurrent appropriations and total surcharges for both school levels over the period of 1998-2006. The results show a similar level of inequality in per-pupil budgetary recurrent appropriations over the nine years from 1998 to 2006 . This is not surprising since the Gini coefficients represent the level of inequality across provinces, while the rural taxation reforms are, for the most part, a rearrangement of fiscal relations at the subprovincial level. Unless the rural taxation reforms have led to higher amounts of recurrent appropriations for education in less developed provinces, the reforms will not have visible equalization effects at the inter-provincial level. Comparing the level of inequality between urban and rural schools, we find that in urban schools the inequality

\footnotetext{
${ }^{19}$ Urban surcharges for education are levied at a certain percentage on value-added tax, business tax, and consumption tax. Rural surcharges are imposed as a certain percentage of enterprise profits or sales revenue obtained by villages and townships, and farmers' per capital net income. Local surcharges are those levied for education in addition to urban and rural surcharges (China Education Finance Statistical Yearbook, 1999).
} 
has increased slightly over the period of 1998-2006, possibly due to widening economic and income disparities. In rural areas, the inequality remained at almost the same level after financial responsibilities were centralized from townships or villages to counties, which may have led to more equitable budgetary-recurrent appropriations. In addition, Table 3 shows that the level of inequality in total surcharges has increased drastically since 2000. Since the implementation of rural taxation reforms, the Gini coefficients for total surcharges in rural areas have become much higher than in urban areas. This indicates that the reforms may have created some differential impact on the usage of urban and rural surcharges across provinces and between urban and rural areas. Examining the composition of revenue sources for total surcharges, we find that change in the level of inequality mainly came from the rapid increase in "urban surcharges," which were available for both urban and some rural schools, although the reforms effectively curtailed rural surcharges and the inequality thereof.

On the expenditure side, Table 4 presents the Gini coefficients of per-pupil recurrent expenditures, personnel expenditures, and capital expenditures. Overall, the levels of inequality for capital expenditures were around 0.6 and 0.7 , much higher than that for recurrent expenditures (mostly personnel spending), which are around 0.2 to 0.3 . This can be explained by the fact that school capital expenditures heavily relied on extrabudgetary sources, of which local governments had uneven fiscal capacity. The alarming level of capital finance disparity may account for the high percentage of school buildings in dilapidated condition in many poor and rural areas (Li 2008), a situation that did not improve much even after recent rural taxation reforms. For both recent expenditures and their subset personnel expenditures, the table shows that the level of inequality continued 
to be higher in rural areas than in urban areas, and both increased during 1998-2006. The results did not show any equalization effect of rural taxation reforms on the personnel spending per se in rural schools (at the provincial level), despite that personnel spending has been guaranteed by governmental budgetary funds in recent years.

Finally, following the Lerman and Yitzhaki (1985) approach, we decompose the contribution of various categories of spending to the dispersion of per-pupil total spending for compulsory education. The analyses show that, for both school levels in almost all of the years, personnel spending (mostly teacher salary guaranteed by government budgetary appropriations) has the highest significant marginal effect in absolute value on the inequality of per-pupil total spending in comparison to nonpersonnel and capital spending, because personnel spending accounts for a very high proportion of the total spending. In addition, inequality of personnel spending for rural schools appeared to be somewhat different prior to and after the rural taxation reforms. The marginal effect of personnel spending on total spending inequality turned negative after the implementation of the Tax-for-Fee reform in 2000. This suggests that, although the personnel spending by itself remained unevenly distributed, it has helped to bring down the level of overall inequality in per-pupil total spending for compulsory education across provinces in recent years.

\section{Conclusion and Discussions}

In summary, the rural taxation reforms implemented since 2000 have made some progress in restructuring the financing mechanism for China's compulsory education. The adequacy of China's compulsory education in rural areas has improved to some 
extent after the implementation of these reforms. The increase of governmental funding led to more sufficient recurrent spending, especially personnel spending; however, insufficient capital spending remained a serious challenge for schools, especially those in rural areas. The increase in intergovernmental transfers and budgetary spending also contributed to reducing the overall inequality in total expenditures for compulsory education, but the reforms did not show any significant impact in closing the gap in the level of educational spending between rural and urban areas, or alleviating the inequality in educational revenue and spending across provinces or between rural and urban areas over the period of 1998-2006. Obviously, further reforms are needed to improve the financing system of China's compulsory education.

The issues surrounding compulsory education are actually manifestations of China's imbalanced intergovernmental fiscal arrangements in the country's economic and administrative transition. To better understand the origins of these issues or to suggest policy options for addressing them, it is helpful to discuss them from the perspectives of fiscal decentralization and intergovernmental fiscal relations.

Over the last several decades, fiscal decentralization has been a widely discussed topic for emerging and transition economies, with the premise that there can be gains of efficiency, effectiveness, and accountability by moving government closer to the people (Musgrave 1983). Related experiments, however, have brought mixed and complicated results (for instance, Davoodi and Zou 1998). Experiences show many counter arguments that favor fiscal centralization, such as control at the central government level, the direction of investment on social overhead, and equalization of basic public service delivery (Bahl 1999). Scholars come to the understanding that the design of 
intergovernmental fiscal relations, whether decentralization or centralization, is a dynamic process that should be studied in the comprehensive context including types and features of services, political structure, and administrative capacity at all levels of governments (see the twelve "implementation rules for fiscal decentralization" in Bahl 1999). The case of rural taxation reforms and China's compulsory education finance provide a great example to study such a dynamic process.

What has caused the excessive burden of fees and charges for farmers in China? The fundamental reason is China's imbalanced intergovernmental fiscal arrangements, which combine very decentralized fiscal responsibilities with a highly centralized revenue system, especially after the 1994 tax-assignment reform (Lin et al. 2007). With limited tax capacity to fulfill public service mandates (such as compulsory education), local governments, especially those in rural areas, had to rely on extra-budgetary sources through all kinds of fees and charges. These informal taxation sources easily got out of control due to local decision makers' "rent-seeking" behavior, because (1) fees and charges were less transparent than formal taxes, (2) rural governments were not held accountable to local farmers, and (3) there were insufficient mechanisms for monitoring and controlling from higher level of governments due to information asymmetry. Recent rural taxation reforms have prohibited local governments in rural areas from eliciting illegal fees and charges. However, unless the issue of imbalanced intergovernmental fiscal arrangements is solved — either through centralizing some service responsibilities, enhancing local taxing power, or providing additional intergovernmental transfersinformal revenue sources are sure to regain their importance. They even may turn 
excessive over time, as suggested by the "Huang Zhongxi's Law," based on many similar stories from Chinese history (Qin 2003).

Similar examples are abundant in the U.S. For example, after the passage of Proposition 13 in California, the newly-imposed tight tax and expenditure limits required large reductions in property taxes and effectively prevented local governments from replacing those property tax revenues in the future. Because local governments could not increase school spending to desired levels, many of them have turned to increased fees, parent contributions or fundraising by school associations, and other ways to generate extra revenue (Fisher 2007).

Why has compulsory education in China been persistently underfunded? On one hand, the level of education investment continued to be low in China even compared with other developing countries, and the situation remained unchanged after additional intergovernmental transfers were provided as components of the rural taxation reforms in recent years. In fact, investigations have found that intergovernmental transfers tended to be directed to purposes other than education unless the funding was earmarked and closely monitored ( $\mathrm{Li}$ 2008). Other than economic reasons, the unchanging situation is, in part, due to the fact that responsibility for the provision of compulsory education rests with the lowest levels of government. According to Bahl (1999), higher-level governments should play a role in services with substantial externalities, such as education, because local governments such as townships or villages will not have incentives for providing a sufficient level of such services.

Another reason for underfunding lies in the accountability mechanism and the appraisal system. Local government officials in China are held accountable by higher- 
level governments, with their performance typically measured by short-term indicators of economic development, such as major infrastructure projects, urban expansion and beautification, and the growth of GDP. Thus they have the tendency to place a low priority on compulsory education that has effects mostly in the long run (Li 2008). On the other hand, China's compulsory education is very unevenly provided. The education inequality is, in part, a manifestation of economic and fiscal disparities across different regions and between urban and rural areas (Wang and $\mathrm{Hu}$ 1999), but it is also caused by the over-decentralization of education administration. Since the 1970s, most states in the U.S. have attempted to equalize educational opportunity across districts, resulting in increased state financial commitments and corresponding decreases in local financial responsibility. In consequence, the state share of school finance has surpassed the local share in most years since then (Fisher 2007). China's 2001 education reform to move the responsibility of compulsory education from the township and village levels to the county level is heading towards the right direction, but the county-level of government is still very low for shouldering the major responsibilities of compulsory education, unless substantial intergovernmental transfers for education can be provided by higher levels of government.

\section{What future directions should China take for the provision of compulsory} education? As has been shown in this study, the investigation of China's education reform cannot be separated from China's rapid transition of general fiscal and administrative reforms. Issues of insufficient and uneven funding in compulsory education can only be solved by reforming intergovernmental fiscal relations to better match fiscal responsibilities with revenue authorities, and through reforms of political 
and administrative systems to better align governmental accountability. Lin et al. (2007) suggest that local governments should be provided with more formal tax autonomy, such as enacting local property taxes, and should encourage more meaningful participation by expanding local democracy in the long run. In addition, we argue that the central or provincial governments should place a higher priority on the financing and administration of compulsory education to secure a sufficient and equitable delivery of public services.

Overall, this analysis of rural taxation reforms in the Chinese context suggests that a reform with the good intention of reducing local tax burdens by restricting local governmental revenue choices may have undue effects on the provision of an essential public service. Solving these issues requires corresponding reforms in intergovernmental fiscal relations to rebalance fiscal responsibilities and revenue authorities, and to maintain proper accountability for local officials. The pursuit of an equalized and adequate education finance system and the balance between more state involvement and control with local autonomy have also been a central issue of debate in the U.S. While it has been popular to push for more centralized funding for creating greater equity, policymakers in the U.S. may learn from this Chinese experience when they reform their school finance systems, thereby avoiding similar unintended consequences. 


\section{References}

Bahl, Roy. 1999. Implementation rules for fiscal decentralization. Atlanta: International Studies Program, Andrew Young School of Policy Studies, Georgia State University.

Brandt, Loren, and Carsten A. Holz. 2006. Spatial price differences in China: Estimates and implications. Economic Development and Cultural Change 55(1): 43-86.

Carnoy, Martin. 1995. International encyclopedia of economic of education. Oxford: Elsevier Science \& Technology Books.

Chen, Xiwen. 2003. A study on China's county and township public finance and farmer income growth (in Chinese). Shanxi Economic Press.

Davoodi, Hamid, and Heng-fu Zou. 1998. Fiscal decentralization and economic growth: A cross-country study. Journal of Urban Economics 43: 244-257.

Ding, Yanqing. 2003. Compulsory education in China's minority districts: Underfunded or preferably financed? Paper presented at the International Conference on Chinese Education, February 7, in New York City, NY.

Du, Y., and S. Wang. 2000. Disparities in educational development (Jiaoyu fazhan de bupingheng). In Economic Analysis of Education Policy (Jiaoyu zhengce de jingji fengxi), ed. M. Tsang, X. Wei, and J. Xiao (eds.), 76-109. Beijing: Beijing People's Education Press.

Fisher, Ronald. 2007. State and local public finance. 3rd ed. Mason, OH: Thomson South-Western.

Jiang, Minghe, and H. Zhang. 1999. Disparities in education spending (Jiaoyu jinfei bupingheng). Shanghai: Shanghai Institute of Human Resources Development.

Kennedy, J. J. 2007. From the tax-for-fee reform to the abolition of agricultural taxes: The impact on township governments in north-west China. The China Quarterly 189(1): 43-59.

Lerman, R., and S. Yitzhaki. 1985. Income inequality effects by income source: A new approach and applications to the United States. The Review of Economics and Statistics 67: 151-156.

Levin, Henry M. 1995. Raising educational productivity. In The International Encyclopedia of Economics of Education, ed. M. Carnoy, 283-291. Oxford: Pergamon.

$\mathrm{Li}$, Xiangyun. 2008. The reform of the compulsory education finance system in the evolution of the finance system in China (Woguo caizhengtizhi bianqianzhong de yiwujiaoyu caizheng zhidu gaige). Beijing: Peking University Press.

Lin, Yifu, Ran Tao, and Mingxiu Liu. 2007. Rural taxation and local governance reform in China's economic transition: Origins, policy responses and remaining challenges. Working Paper, Stanford Center for International Development. 
Lu, Wei et al. 2004. The public investment policy for rural compulsory education (Nongcun jichujiaoyu de gonggong touru zhengce), The Economic and Social Development Research Institute of Northeastern University of Finance and Economics (Dongbei caijingdaxue jingji yu shehuifazhan yanjiuyuan ketizu), http://academy.dufe.edu.cn/resources/neibuwengao/images/nongcunjichujiaoyugonggong touru.pdf (accessed March 29, 2009).

Ministry of Education, the People's Republic of China. 2005. Educational Statistics Yearbook of China. Beijing: People's Education Publishing House.

Ministry of Education, and National Bureau of Statistics, the People's Republic of China. 1999-2007. China Education Finance Statistical Yearbook. Beijing: the Publishing House of National Bureau of Statistics of China.

Musgrave, Richard A. 1983. "Who Should Tax, Where, and What?" in Tax Assignment in Federal Countries. Edited by Charles McLure, Jr. Canberra: Centre for Research on Federal Financial Relations, Australian National University.

Pan, Tiansho. 2000. On the Regional Disparity of Financing Compulsory Education across County Level (Woguo xianji yiwujiaoyu touzi de diqu cayi jiqi yingxiang yinsu fenxi). Education and Economy (Jiaoyu yu jingji) 4: 36-44.

Qin, Hui. 2003. "Huang Zhongxi Laws" and system foundation of tax-fee reform: Historical experience and the selection of reality. Tax Administration Research 7: 2-8 (in Chinese).

Tsang, Mun. 1994. Costs of education in China: Issues of resource mobilization, equality, equity, and efficiency. Education Economics 2(3): 287-312.

Tsang, Mun. 1996. Financial reform of basic education in China. Economics of Education Review 15(4): 423-444.

Tsang, Mun. 2000. Education and national development in China since 1949: Oscillating policies and enduring dilemmas. In China Review, ed. Lau Chung-ming and Jianfa Shen, 579-618. Hong Kong: The Chinese University of Hong Kong.

Tsang, Mun. 2001. Intergovernmental grants and the financing of compulsory education in China, http://www.tc.columbia.edu/centers/coce/pdf_files/a1.pdf (accessed March 29, 2009).

Tsang, Mun. 2002. Establishing and developing a substantial and regularized scheme of intergovernmental grants in compulsory education in China. Harvard China Review 5: $11-15$.

Tsang, Mun. 2005. Resource utilization and disparities in compulsory education in China. China Review 5(1): 1-31.

Tsang, Mun, and Yanqing Ding. 2003. Financial challenges in compulsory education and intergovernmental education grants. Peking University Education Review 1(1): 84 94.

The development report of China's education (Zhongguo jiao yu fa zhan bao gao). 2005-2006. Beijing: $21^{\text {st }}$ Century Education Research Institute. 
Wang, Shaoguang. 1997. China's 1994 fiscal reform: An initial assessment. Asian Survey 37(9): 801-817.

Wang, Rong. 2001. Regional disparity in school finance in China (Woguo yiwujiaoyu de diqu cayi yanjiu). Beijing: International Conference on Economics of Education.

Wang, Shaoguang, and Hu Angang. 1999. The political economy of uneven development: The case of China. Armonk, N.Y.: M.E. Sharpe.

Wang, Rong. 2002. A study on the disparities in compulsory education funds across regions in China. In Providing adequate resource for education: Collection of essays in the International Conference on Economics of Education, ed. Min, Weifang et al. Beijing: People's Education Press.

Wong, Christine P., and Richard M. Bird. 2005. China's Fiscal System: A Work in Progress. Working paper 05-20, International Studies Program, Andrew Young School of Public Policy, Georgia State University, http://aysps.gsu.edu/isp/files/ispwp0520.pdf (accessed March 29, 2009).

Yep, Ray. 2004. Can 'tax-for-fee' reform reduce rural tension in China: The process, progress and limitations. The China Quarterly 177: 42-70.

Zhao, Zhirong. 2009. Forthcoming. Fiscal decentralization and provincial-level fiscal disparities in China: A Sino-U.S. comparative perspective. Public Administration Review. 
Table 1. Per-Pupil Spending (in RMB), 1998 and 2006

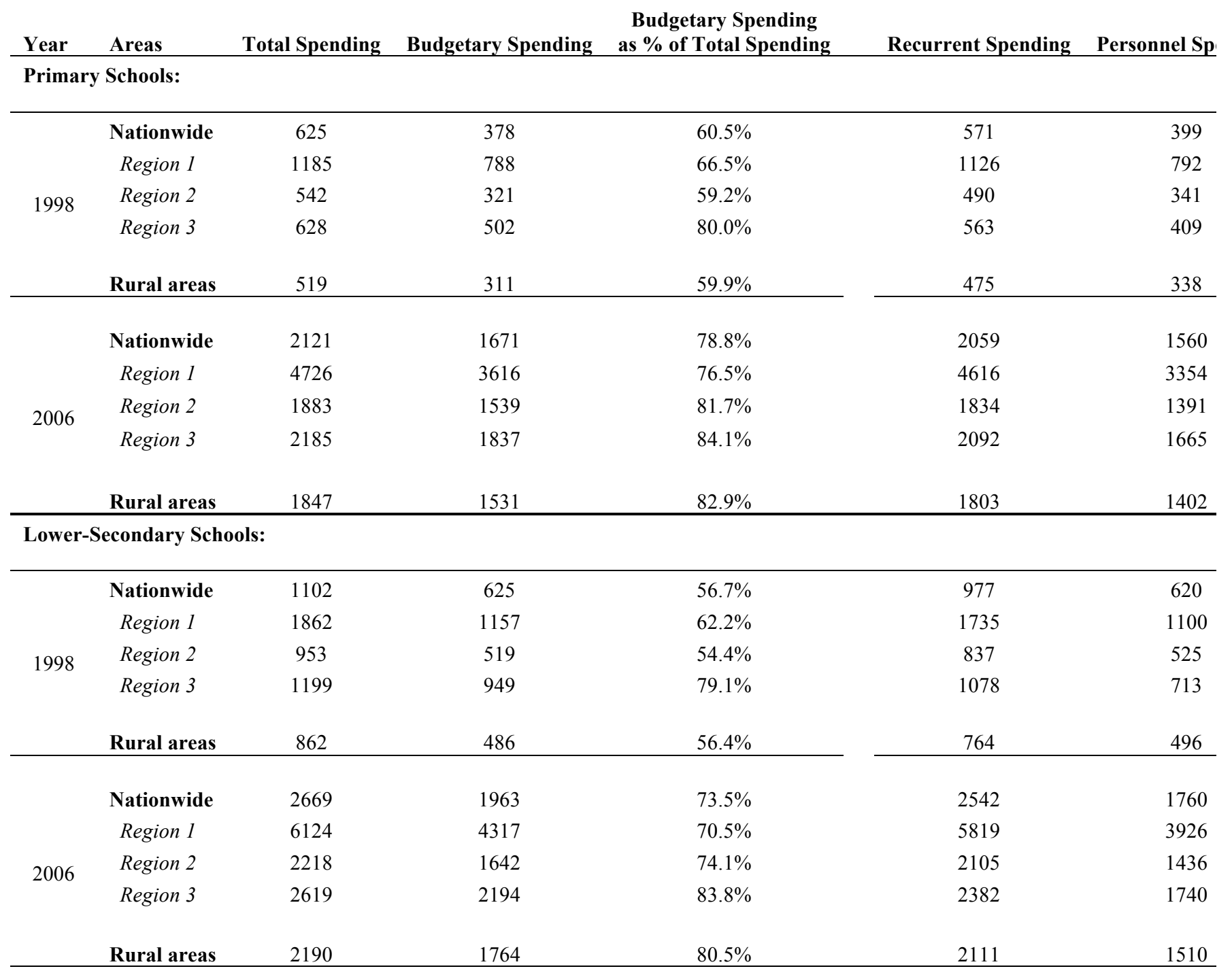

Note: During 1998-2006, the RMB-USD exchange rate fluctuates around 8.0:1. 
Table 2. Changing Sources of Funding for Education Over Time (RMB, in Billions)

\begin{tabular}{|c|c|c|c|c|c|}
\hline \multirow[t]{2}{*}{ Year } & \multirow[t]{2}{*}{ Sources } & \multicolumn{2}{|c|}{ Primary } & \multicolumn{2}{|c|}{ Lower-Secondary } \\
\hline & & Amount & $\%$ of Total & Amount & $\%$ of Total \\
\hline \multirow[t]{10}{*}{1998} & $\begin{array}{l}\text { Government budgetary } \\
\text { funds }\end{array}$ & 52.2 & $60.8 \%$ & 32.2 & $57.6 \%$ \\
\hline & Extra-budgetary funds: & & & & \\
\hline & Surcharges & 12.5 & $14.6 \%$ & 8.2 & $14.7 \%$ \\
\hline & Institutional revenue & 12.4 & $14.4 \%$ & 9.3 & $16.6 \%$ \\
\hline & Tuition and fees & 8.8 & $10.2 \%$ & 6.0 & $10.8 \%$ \\
\hline & Enterprise-run institutions & 2.0 & $2.3 \%$ & 1.3 & $2.4 \%$ \\
\hline & Social contributions & 5.8 & $6.8 \%$ & 4.2 & $7.4 \%$ \\
\hline & Others & 1.0 & $1.2 \%$ & 0.7 & $1.3 \%$ \\
\hline & Subtotal & 33.7 & $39.2 \%$ & 23.7 & $42.4 \%$ \\
\hline & Total & 86.0 & $100.0 \%$ & 55.9 & $100.0 \%$ \\
\hline \multirow[t]{10}{*}{2006} & $\begin{array}{l}\text { Government budgetary } \\
\text { funds }\end{array}$ & 186.0 & $84.3 \%$ & 116.8 & $76.9 \%$ \\
\hline & Extra-budgetary funds: & & & & \\
\hline & Surcharges & 10.9 & $5.0 \%$ & 9.7 & $6.4 \%$ \\
\hline & Institutional revenue & 16.6 & $7.5 \%$ & 19.1 & $12.5 \%$ \\
\hline & Tuition and fees & 9.6 & $4.4 \%$ & 10.3 & $6.8 \%$ \\
\hline & Enterprise-run institutions & 0.7 & $0.3 \%$ & 0.8 & $0.5 \%$ \\
\hline & Social contributions & 2.5 & $1.2 \%$ & 1.9 & $1.3 \%$ \\
\hline & Others & 3.9 & $1.8 \%$ & 3.7 & $2.5 \%$ \\
\hline & Subtotal & 34.7 & $15.7 \%$ & 35.1 & $23.1 \%$ \\
\hline & Total & 220.7 & $100.0 \%$ & 151.9 & $100.0 \%$ \\
\hline
\end{tabular}

Note: During 1998-2006, the RMB-USD exchange rate fluctuates around 8.0:1. 
Table 3. Gini Coefficient of Two Major Revenue Sources (1998-2006)

\begin{tabular}{|c|c|c|c|c|c|c|}
\hline \multirow[t]{2}{*}{ Year } & \multicolumn{3}{|c|}{ Primary Schools } & \multicolumn{3}{|c|}{ Lower-Secondary Schools } \\
\hline & All & Urban & Rural & All & Urban & Rural \\
\hline \multicolumn{7}{|c|}{ Per-Pupil Budgetary Recurrent Appropriations: } \\
\hline 1998 & 0.26 & 0.20 & 0.26 & 0.25 & 0.22 & 0.26 \\
\hline 1999 & 0.26 & 0.21 & 0.27 & 0.27 & 0.23 & 0.28 \\
\hline 2000 & 0.27 & 0.23 & 0.27 & 0.25 & 0.21 & 0.27 \\
\hline 2001 & 0.26 & 0.22 & 0.26 & 0.23 & 0.20 & 0.24 \\
\hline 2002 & 0.25 & 0.22 & 0.25 & 0.23 & 0.20 & 0.21 \\
\hline 2003 & 0.27 & 0.24 & 0.26 & 0.25 & 0.23 & 0.23 \\
\hline 2004 & 0.27 & 0.25 & 0.27 & 0.26 & 0.25 & 0.25 \\
\hline 2005 & 0.27 & 0.25 & 0.28 & 0.27 & 0.27 & 0.27 \\
\hline 2006 & 0.26 & 0.25 & 0.26 & 0.25 & 0.26 & 0.26 \\
\hline \multicolumn{7}{|c|}{ Per-Pupil Total Surcharges: } \\
\hline 1998 & 0.26 & 0.27 & 0.24 & 0.25 & 0.28 & 0.27 \\
\hline 1999 & 0.25 & 0.26 & 0.25 & 0.31 & 0.32 & 0.28 \\
\hline 2000 & 0.34 & 0.34 & 0.32 & 0.34 & 0.34 & 0.33 \\
\hline 2001 & 0.42 & 0.41 & 0.38 & 0.37 & 0.33 & 0.41 \\
\hline 2002 & 0.58 & 0.48 & 0.58 & 0.51 & 0.41 & 0.56 \\
\hline 2003 & 0.65 & 0.52 & 0.68 & 0.54 & 0.43 & 0.67 \\
\hline 2004 & 0.62 & 0.50 & 0.67 & 0.58 & 0.46 & 0.68 \\
\hline 2005 & 0.55 & 0.40 & 0.65 & 0.58 & 0.49 & 0.64 \\
\hline 2006 & 0.54 & 0.44 & 0.58 & 0.52 & 0.45 & 0.61 \\
\hline
\end{tabular}


Table 4. Gini Coefficient of Per-Pupil Expenditures (1998-2006)

\begin{tabular}{|c|c|c|c|c|c|c|}
\hline \multirow[t]{2}{*}{ Year } & \multicolumn{3}{|c|}{ Primary Schools } & \multicolumn{3}{|c|}{ Lower-Secondary Schools } \\
\hline & All & Urban & Rural & All & Urban & Rural \\
\hline \multicolumn{7}{|c|}{ Per-Pupil Recurrent Expenditures } \\
\hline 1998 & 0.23 & 0.19 & 0.21 & 0.23 & 0.19 & 0.22 \\
\hline 1999 & 0.23 & 0.20 & 0.21 & 0.24 & 0.20 & 0.23 \\
\hline 2000 & 0.24 & 0.21 & 0.22 & 0.22 & 0.18 & 0.23 \\
\hline 2001 & 0.25 & 0.21 & 0.23 & 0.22 & 0.18 & 0.21 \\
\hline 2002 & 0.25 & 0.21 & 0.24 & 0.23 & 0.20 & 0.20 \\
\hline 2003 & 0.27 & 0.23 & 0.25 & 0.25 & 0.23 & 0.22 \\
\hline 2004 & 0.28 & 0.26 & 0.26 & 0.27 & 0.25 & 0.24 \\
\hline 2005 & 0.27 & 0.24 & 0.27 & 0.27 & 0.26 & 0.25 \\
\hline 2006 & 0.26 & 0.25 & 0.27 & 0.27 & 0.26 & 0.27 \\
\hline \multicolumn{7}{|c|}{ Per-Pupil Personnel Expenditures: } \\
\hline 1998 & 0.23 & 0.19 & 0.22 & 0.22 & 0.19 & 0.22 \\
\hline 1999 & 0.23 & 0.19 & 0.23 & 0.23 & 0.20 & 0.23 \\
\hline 2000 & 0.24 & 0.20 & 0.23 & 0.22 & 0.19 & 0.24 \\
\hline 2001 & 0.24 & 0.21 & 0.24 & 0.22 & 0.19 & 0.21 \\
\hline 2002 & 0.24 & 0.20 & 0.24 & 0.22 & 0.19 & 0.20 \\
\hline 2003 & 0.25 & 0.22 & 0.25 & 0.24 & 0.22 & 0.22 \\
\hline 2004 & 0.26 & 0.23 & 0.26 & 0.25 & 0.24 & 0.24 \\
\hline 2005 & 0.26 & 0.23 & 0.27 & 0.29 & 0.31 & 0.26 \\
\hline 2006 & 0.26 & 0.24 & 0.27 & 0.27 & 0.27 & 0.27 \\
\hline \multicolumn{7}{|c|}{ Per-Pupil Capital Expenditures: } \\
\hline 1998 & 0.59 & 0.55 & 0.66 & 0.56 & 0.50 & 0.57 \\
\hline 1999 & 0.55 & 0.57 & 0.65 & 0.55 & 0.54 & 0.63 \\
\hline 2000 & 0.58 & 0.60 & 0.68 & 0.69 & 0.61 & 0.82 \\
\hline 2001 & 0.59 & 0.58 & 0.65 & 0.79 & 0.49 & 0.46 \\
\hline 2002 & 0.56 & 0.55 & 0.60 & 0.49 & 0.48 & 0.54 \\
\hline 2003 & 0.65 & 0.61 & 0.71 & 0.75 & 0.56 & 0.52 \\
\hline 2004 & 0.55 & 0.51 & 0.60 & 0.69 & 0.45 & 0.45 \\
\hline 2005 & 0.52 & 0.58 & 0.52 & 0.68 & 0.46 & 0.57 \\
\hline 2006 & 0.53 & 0.59 & 0.58 & 0.62 & 0.46 & 0.63 \\
\hline
\end{tabular}

